\title{
Humanização na Gestão um Serviço Odontológico: Acolhimento com Avaliações de Risco e Necessidade de Tratamento
}

\author{
Martino, Luiz Vicente Souza \\ Serviço Social do Comércio - Sesc — Ivsmartino@ig.com.br
}

Introdução: um dos valores que norteiam a humanização em saúde é a indissociabilidade entre atenção e gestão. Modelos de atenção, gestão e relações de acesso aos serviços podem ser modificados por dispositivos tecno-assistenciais, tais como o acolhimento. o acesso é um dos problemas dos serviços de saúde e evidencia particularidades sobre desigualdades sociais em sua utilização. a saúde bucal traduz bem tais características. Investigações de aspectos biológicos ligados ao risco individual orientam a organização da demanda assistencial e ações coletivas. Nessa linha, avaliações de risco conjugadas com o acolhimento são úteis ferramentas na identificação de doenças bucais e na busca da equidade na atenção em saúde. Objetivo: Este trabalho objetiva descrever a maneira como um Serviço Odontológico (SO) pertencente a uma Unidade Operacional (UO) de uma Organização Paraestatal que tem por finalidade proporcionar cultura, lazer e bem-estar a um público-alvo específico trabalhou a demanda por seus serviços entre os anos de 2011 e 2013. Método: o SO composto de 4 consultórios odontológicos, 12 Dentistas, 4 Auxiliares de Saúde Bucal e 2 Recepcionistas foi inaugurado em novembro de 2011 e em dezembro do mesmo ano, dezembro de 2012 e agosto de 2013 abriu inscrições para realização de tratamento odontológico, fundamentando seu discurso junto ao público-alvo em duas prerrogativas, prestação de assistência odontológica a todos que comparecessem a UO para buscá-la nos dias de inscrição e priorização de atendimento àqueles que se encontrassem em piores condições nas avaliações de risco e necessidade de tratamento odontológico, realizadas com critérios previamente estabelecidos para cárie dentária, doença periodontal e necessidade de prótese dentária, durante os processos de inscrição. Complementando o processo de acolhimento, realizaram-se bate-papos explicativos sobre os serviços prestados pelo SO e a maneira como as inscrições foram planejadas com o intuito de efetivar o acolhimento ao público. Resultados: As inscrições realizadas em 2011 receberam 1.116 pessoas, as de 2012 contaram com 831 pleiteantes a tratamento e as de 2013 terminaram com 816 pessoas. nas inscrições de 2012 e 2013 houve um percentual acima de $90 \%$ de pessoas que não haviam realizado tratamento no SO em anos anteriores, ou seja, o SO atendeu mais de 2.500 pessoas desde sua inauguração. Conclusões: Inscrições baseadas no acolhimento com avaliações de risco e necessidade de tratamento configuraram-se como intervenção decisiva na organização e efetivação da promoção de saúde, pois se fizeram a partir da análise, problematização e proposição da própria equipe que foi sujeito de seu processo de trabalho. Além disso, houve a organização do acesso dos usuários ao SO, mudando a forma burocrática de entrada por filas e ordem de chegada que normalmente ocorre em serviços similares e a humanização das relações entre profissionais e usuários no que se refere à forma de escuta de problemas e demandas.

Martino, Luiz Vicente Souza. Humanização na Gestão um Serviço Odontológico: Acolhimento com Avaliações de Risco e Necessidade de Tratamento. In: Anais do Congresso Internacional de Humanidades \& Humanização em Saúde [= Blucher Medical Proceedings, num.2, vol.1]. São Paulo: Editora Blucher, 2014. ISSN 2357-7282

DOI 10.5151/medpro-cihhs-10811 